This is a self-archived version of an original article. This version may differ from the original in pagination and typographic details.

Author(s): Pučètaitè, Raminta; Lämsä, Anna-Maija; Norvaišaitè, Marija

Title: Masculinity in flux? : Male managers navigating between work and family

Year: 2020

Version: Accepted version (Final draft)

Copyright: @ 2020 Routledge

Rights: In Copyright

Rights url: http://rightsstatements.org/page/InC/1.0/?language=en

Please cite the original version:

Pučètaitè, R., Lämsä, A.-M., \& Norvaišaitè, M. (2020). Masculinity in flux? : Male managers navigating between work and family. Journal of Baltic Studies, 51(2), 179-198.

https://doi.org/10.1080/01629778.2020.1746369 


\section{Masculinity in flux? Male managers navigating between work and family}

Pucetaite Raminta, Lämsä Anna-Maija \& Norvaisaite Marija. Masculinity in flux? Male managers navigating between work and family. Journal of Baltic Studies.

The paper sheds light on male managers' experience as fathers in a post-Soviet context, Lithuania. This empirical study of 12 male managers' experiences of work-family integration (WFI), their ways of coping with negative experiences and the role of organizations in reducing conflict and enriching WFI, reveal the emergence of a new paternal identity: fathers who perceive their role as care-givers but for whom this is still subordinate to the dominant role of breadwinner. Relying on their wife is men's dominant coping strategy. Organizations are perceived as family unfriendly. The managerial implications of the need for organizational support are discussed.

Key words: equality, fatherhood, gender, Lithuania, men managers, masculinity, postSoviet context, work-family integration

\section{Introduction}

Technological advances and the 24/7 economy raise a number of challenges for the ways individuals handle the work-family domains and social well-being. Prior research indicates that the experiencing conflict between work and family accounts for negative employee outcomes such as absenteeism, low job satisfaction, loss of dignity, decreased efficiency, and stronger intentions to leave (Allen et al. 2000; Bolton 2011; Mäkelä et al. 2017). In contrast, individuals who manage their work and family domains well experience security in their life status, enrichment of their personality and an enhanced sense of well-being (Graham and Dixon 2014; Greenhouse and Powell 2006; Parasuraman and Greenhouse 2002). For these reasons the workfamily balance has come onto the political agenda, particularly in the EU (Hobson 2011). Obviously, work and family integration is an important constituent of quality of life, with implications for workforce productivity, organizational competitiveness and social welfare.

Research in European societies shows that a majority of both men and women expect to be able to integrate work and family (Hobson 2011). In addition, political and economic changes have led to transformations in gender identities and family models (Crespi and Ruspini 2015), with 
the questioning of traditional gender roles and the extent to which men participate in the rearing of their children. The increased participation of women in economic life, dual income models, the political discourse on gender equality, and social media have set new expectations for men's masculinity, including the expectation that they should become more involved as fathers. Yet, paradoxically, despite the increasing number of men willing to invest in family life, most research, most organizational practices and most public discussion of work-family integration (hereafter WFI) consider the topic from the viewpoint of women (Hobson and Fahlen 2009; Heikkinen and Lämsä 2017; Kangas, Lämsä, and Heikkinen 2017), as if the relationship was not relevant to men at all. Drawing on Doldor, Anderson, and Vinnicombe (2013) we argue that attention to experiences of WFI by not only women but also men is needed as dilemmas in this field may be indicative of social structures of inequality that call for systemic changes in gender roles. In particular, the ideas and assumptions of traditional masculinity expected from men in the context of WFI need to be challenged and more space created for other types of masculinities.

In this paper we aim to contribute to the academic discourse on men's masculinity in the integration of work and family in the post-Soviet context by empirically exploring male managers' experiences of WFI, their ways of dealing with negative experiences and the sources of conflict and enrichment in their roles. More precisely, we attempt to answer three research questions. RQ1: How do men managers experience WFI in a post-Soviet context? RQ2: How do they cope with negative experiences? RQ3: What is the role of the organization in shaping negative and/or positive experiences of WFI?

Male managers are a relevant group to study because the tension between work and family life could be particularly high for managers who are expected, on the one hand, to work long hours, be available 24/7 and act as hard-working role models and, on the other hand, to be involved, participating parents. Their perspectives on WFI have, however, been little voiced (Heikkinen and Lämsä 2017; Kangas, Lämsä, and Heikkinen 2017). Moreover, the techniques that male managers use to cope with this strain in different organizational contexts call for researchers' attention (Burnett et al. 2013; Crespi and Ruspini 2015; Gatrell 2007; Graham and Dixon 2017) as they may be indicative of the maintenance of stereotypes about gender roles and the inefficient use of (individual, organizational and public) resources. 
In addition to individual coping strategies, we are interested in the support provided by organizations to individuals through workplace practices, as workplaces may not always be ready to recognize fatherhood. Even in family-friendly Nordic societies, fathers are reported to be discouraged from taking parental leave because of the employer's attitude that male employees are indispensable at work (Lammi-Taskula 2006). As indicated by Burnett et al.'s (2013, 632) study, fathers at work keep their needs silent, suggesting the terms "invisible" fatherhood or "ghost" fatherhood in workplaces. Ignoring parental needs in the context of rising expectations of men's more active participation in the family domain may lead to more stress at work. Thus, research into organizational practices may be able to suggest improvements in the workplace that would have beneficial outcomes at the managerial level. This is particularly relevant, considering the power that managers usually have. They play an important role in shaping the organizational culture by promoting certain values and initiating and/or supporting processes that construct or deconstruct gendered organizations (Acker 1990) as well as individual and social identities. As men still dominate the managerial echelons worldwide, men's awareness of WFI and support for it can ease tensions between the work and family domains and bring about greater equality at work not only for themselves but for other people, too (Heikkinen 2015).

This paper also addresses the need to explore men's experiences of WFI in different societal contexts, which has received little attention in prior research (Heikkinen 2015; Mihelič 2014). In particular, we focus on the post-Soviet context, which deserves attention for its particular representation of masculinity. In Soviet times, the image of a man that was constructed by representations in public discourse and media related mainly to physical power, and aspects of private relationships such as fatherhood were not explicitly represented as a part of a man's identity (Oates-Indruchova 2006; Tereškinas 2009). After the fall of the USSR and the liberalization of society, identity as a businessman has been considered the benchmark of male success, maintaining the traditional image of the man as breadwinner despite the fact that the dual income family/co-habitation model is established in society. Men managers' experiences of WFI in this context are important for capturing social shifts and reconstructing a social reality that may be an obstacle to social well-being. Managers' experiences relate to the academic discourse of changing understandings of masculinities in contemporary societies. From the perspective of conceptualization, drawing on the work of Connell (1995), our paper contributes to knowledge of human experiences in dealing with challenges that arise as a result of gender role expectations. 


\section{Conceptual framework}

\section{Work-family integration as conflict and enrichment}

Following Carlson, Grzywacz, and Zivnuska (2009), who discuss the difference between workfamily balance and the related concepts of work-family conflict and enrichment, in this paper we use the term work-family integration (WFI), which we consider to be normatively more neutral than the term work-family balance and conceptually to encompass both conflict and enrichment. Hence we define WFI as a bidirectional relationship between work and family life with negative and positive dimensions (Grzywacz and Marks 2000). The negative dimension is manifested through conflict and negative emotional spillover from one domain to the other. For example, an excessive workload may result in spending less time with the family, due to which a person experiences tension from the interference of work with family life or, on the other hand, from the feeling that excessive family duties are standing in the way of career progress. As Runte and Mills (2004) argue, the conflict dimension has been well documented and has become standard in the human resource management literature, with the result that WFI is popularly perceived as inherently a matter of conflict, particularly over the amount of time available.

A positive dimension of WFI which has come up more recently is enrichment, i.e., the extent to which positive experiences in one role improve the quality of life in the other role (Greenhouse and Powell 2006). Resources which may be usefully transferred include skills, psychological and physical resources, social capital resources, flexibility, and material resources (ibid.). To illustrate, practicing time management skills at work is transferred to family life, which becomes more rewarding because of giving diverse experiences during a limited time or, in the other direction, skills such as negotiation and listening are transferred from the home to workplace relationships, which become more productive and thus enriching. The bidirectionality of WFI means that the two domains interact.

Both the conflict and enrichment dimensions of WFI rest on social role theory (Eagly and Wood 2012), which views individuals as performers of social roles. Social roles are acquired through the process of socialization in the given socio-cultural environment (Berger and Luckman 1966). The idea of learning skills, values and attitudes through socialization is 
supported by the theory of social learning (Bandura 1977), which states that behavior is mostly learnt by observing and copying others, while punishment and reward for the behavior act as a negatively or positively reinforcing mechanism.

Each social role demands resources such as time, energy, commitment and so on, from the individual (Graham and Dixon 2017; Greenhaus and Beutell 1985). One social role may deplete resources from another, causing tension and strain. In the 24/7 economy, time pressure is one of the key factors of tension. Social roles may not only deplete resources but also generate them, resulting in enrichment. According to Sieber (1974), multiple roles enable an individual to acquire skills and physical, psychological, social and material resources, and expand access to them, which increases their ability to meet the obligations of the different roles and buffers failures in any single role. Such experiences enhance self-efficacy and help the individual to cope with problems in one social role or increase their performance in others.

Social roles are built on gendered stereotypes: as socialization takes place in a particular sociocultural context, individuals are prompted to develop personality features and skills that facilitate sex-typical role performance (Eagly and Wood 2012) and gender role characteristics are internalized. As skills are turned into habits, they serve as criteria for self-regulation, raising expectations in other society members, hence performing a function of social regulation (Eagly and Wood 2012, 459). Shared attitudes may turn into stereotypes, raising obstacles to other forms of behaviors that are atypical of genders. For example, when this pattern of developing gender-specific behavior is applied to the working environment, work is divided into female work and male work and gender specific behavior is expected (Parsons and Bales 1955), e.g. assertiveness, calculation and a result-orientation from men and a service-orientation and emotions from women.

Expectations of gender-specific characteristics may affect an individual's choice of profession, work intensity and career anchors (Riska and Novelskaitè 2008; Valackienè 2003). Drawing on Connell's (1995) typology of masculinity, which ranges from hegemonic to subordinate, these expectations affect understandings of masculinity and men's normative behavior. For example, in many societies, the dominant characteristic of masculinity is as provider of economic support for the family and the role of breadwinner. Using this typology, Kangas, Lämsä, and Heikkinen (2017) distinguished different types of involvement on the part of male managers in the role of father, which also indicates changing social expectations with regard 
to men's roles. These types, which describe men's involvement in bringing up children and doing the housework from the least to the most, range from full-time breadwinner through uncommitted, "best bits" of fatherhood to hands-on fatherhood. According to Runte and Mills (2004) and Kaufman (2013), "best bits of fatherhood" is one of the most common types in North America, where social expectations of men becoming more involved fathers have given rise to the concept of "new dads", who contribute to child rearing but mostly on weekends.

Prior research shows that men managers' experiences of WFI vary. Some researchers have found that men are more influenced by the characteristics of their work than by family factors (Fitzpatrick et al. 2012; Gatrell et al. 2013; Nomaguchi, Milkie, and Bianchi 2005). Gatrell et al.'s (2013) findings indicate that in the work environment, children are not considered a problem for men while for women they are. A similar finding was reported by Kangas, Lämsä, and Heikkinen (2017) in their study among Finnish male managers: men managers tend not to construct the work-family relationship as problematic, but rather see it as easy to handle. In contrast, a study of academic fathers by Reddick et al. (2011) showed family as a cause of depleting resources for work.

\section{Individual coping strategies and institutional support for WFI}

Drawing on Goode (1960), Graham and Dixon (2017) note that tension between work and family roles leads to individual coping strategies, which can include compartmentalizing the roles one from another (i.e. keeping the work and family domains separated), delegating role duties to others, avoiding some role relationships entirely (e.g. abstaining from family life or a shared social life because of over-commitment to the work role and its obligations), or expanding certain roles (e.g. joining specific interest or professional clubs to expand the network needed to fulfill obligations at work or in the family). Among individual coping strategies used to buffer excessive demands from the workplace, Reddick et al.'s (2012) study identified getting advice from colleagues on WFI or just their empathetic support, and reliance on the family. This same study found that adhering to traditional gender roles such as fathers as breadwinners and disciplinarians may also develop into an inter-role conflict-easing strategy even in egalitarian families. Reingardienè (2004) notes that coping strategies may also relate to changes in expectations with regard to social roles (e.g., acknowledging the inability to achieve WFI and hiring a nanny, or learning to live with tension) and rationalization techniques. 
The institutional need to be efficient requires that organizations reduce the tensions on their employees and offer them family-friendly practices. To this end, organizations have tried to create and/or reinforce positive experiences in various ways: by giving WFI counselling or mentoring, allowing flexible scheduling, working from home and (un)paid leave, building family-supportive cultures, etc. (Lewis 1997). The availability of these practices can vary depending on national legislation as well as an organization's social orientation (Bailyn 2011; Castro-García and Pazos-Moran 2016). These practices can help to reconstruct not only gendered social structures such as organizations themselves but also societal attitudes and expectations about social roles ascribed to a particular gender in the organization. They therefore have the potential to establish gender equality at work. Socialization processes in the institutional context are the wheels through which change may happen (Deutch 2007; cf. Acker 1990). The introduction and development of practices for WFI depend on the extent to which an organization is generally gender-equality conscious: a study by Haas and Hwang (2013) demonstrates that organizations are more willing to implement practices for WFI for employees who are fathers when they also support equal opportunities for women.

As some studies have indicated, men do not necessarily take advantage of family-friendly policies (Bailyn 2011; Kaufman 2018; Lammi-Taskula 2006; Reddick et al. 2011). The reasons for that are financial loss, lack of moral support from the employer and colleagues, and gendered patterns of sharing care for the child in the family. Some researchers argue that WFI may be bound to the individual's status in the organization. For example, a high status in the organization is related to higher income and more chance of hiring help to do the housework, so that leisure time with a spouse and children is more productive or time can be spent on one's own development, therefore enriching the personality. Therefore, role accumulation and enrichment may apply when explaining the success of WFI in dual partnership families but not necessarily in the case of single parents (cf. Fitzpatrick et al. 2005).

\section{Gender roles in work and family in Lithuania}

Lithuania is a post-Soviet society where, like in many other post-socialist or communist states, public representations of male identity were based on the image of a physically strong worker or soldier and no place was left in political discourse for other images of masculinity, such as care-giver (Oates-Indruchova 2006; Tereškinas 2009). Visual and textual representations of men at that time portrayed them as active in the public field and very rarely in family life, which was left to women. This division sustained a patriarchal order of genders. Women were 
active in the labor market as well, but they alone were given responsibility for housework and the home.

Although the social and economic situation in Lithuania has changed since the regaining of independence in 1990, and working women may now contribute a larger part of the family income, the changes in role distribution are not very significant. A study on gender orientations in Lithuania in 2000 (Purvaneckas and Purvaneckiene 2001) found that family care was perceived as the woman's mission, family as a core value, and the fields of family and work as inherently incompatible and conflicting. The public opinion poll The Crisis of Male Roles in Lithuania, 2002 (Tereškinas 2004) indicates that a man's ability to earn money for his family was prioritized by $72 \%$ of the respondents, followed by the ability to do traditionally men's job about the house and take responsibility for the care and upbringing of children (67\% respondents), and taking care of his female partner (66\%). A study of task-sharing between genders in the household in 2004 added to these findings that most of the unpaid and invisible housework was performed by women, and men led only in repairing household equipment (Juraitė and Zdanevičius 2004).

Joining the EU in 2004 raised social expectations that men would become more involved fathers. In 2006 the Law on Sickness and Maternity Social Insurance of the Republic of Lithuania was amended to give men the right to one month's paid paternity leave. Paid paternity leave of one year had already been legally set in the Labour Code of 2002, but this was very little used. For example, only $1.4 \%$ of parents on leave in 2005 were men taking 1 year or more paternity leave (Drews et al. 2005). One of the explanations for these figures is the social expectation of the man as breadwinner, which conflicts with a man's self-image as a care-giver (ibid.). To change the situation, social advertising campaigns presenting fatherhood and paternity leave as options that were socially desirable and attractive at the individual level were launched with the slogan "Fatherhood drives!" for some time in 2007-2008. The occurrence of a father as an image of masculinity in public discourse could also have contributed to some changes in society, and the percentage of men taking at least one-year paternity leave increased. According to the statistical data of the National Social Insurance Fund, in 2017 men accounted for $22.7 \%$ of those on parental leave (SODRA 2018).

Later studies focusing on masculinity and fatherhood in Lithuania did not reveal any significant changes in men's social attitudes: even young men who were on paternity leave considered 
parental leave to be a female activity and supported traditional task distribution between men and women (Šumskaite 2014; Tereškinas 2006). The image of man as breadwinner is still deeply internalized by men, which explains the social marginalization of unemployed men and, in extreme cases, their self-perception as powerless and emasculated (Bučaitè-Vilkè and Tereškinas 2016; Tereškinas 2014). Women reinforce this image. Šumskaite’s study (2014), for example, indicates that women tend to ascribe the function of breadwinning to men in addition to their role as the (moral) discipliner of children in the family. In this respect, Reiter's (2010) and Tereškinas' (2014) studies on, respectively, young women's and men's orientations towards work and family, present a different view: one of the key themes among the interviewees was postponing parenthood and prioritizing work in order to gain financial security and, in the case of women, independence, which implies a value shift towards a more egalitarian family model and more equality in the distribution of work-family tasks between the partners.

\section{Methods}

The phenomenological approach adopted here draws on the idea that research is based on the meaning structure of those studied, in this case, male managers (Aspers 2009). To this end, 12 Lithuanian men who were fathers and who held managerial positions were approached for interview following the references from personal contacts of the researchers. Their age ranged from 29 to 43 years, 36 being the mean age. All of the men had children, on average two, who were younger than 18 years. All the interviewees were married to mothers of their children and lived with them. All of them had higher education. They came from diverse industry sectors, including construction, logistics, communication and IT services, education, financial services, food processing, and pharmaceuticals, as well as public sector institutions operating in education. The interviewees were contacted by telephone and asked to take part in an interview, which took place at a venue selected by the interviewee. Our interview questionnaire consisted of open-ended questions based on the narrative approach (e.g. tell me how your career evolved? At which stage of career were your children born? How did you share the responsibilities with your wife/spouse, etc.), which allowed informal and open discussion with the interviewees (Bruner 1991; Lämsä et al. 2018). Interviews were conducted face-to-face and lasted from 32 to 72 minutes, the average being 45 minutes. The audio-recorded interviews were transcribed verbatim, which resulted in 148 pages of text. The identities of the interviewees were anonymized by naming them with the letters $\mathrm{A}$ to $\mathrm{L}$. 
After all the interviews were transcribed, the analysis began with the reading and re-reading of the texts. At this stage the aim was to build a thorough overview of the interviewees' experiences of the topic. Next, the meaning units in the texts were identified: pieces of text in the data that contained an idea about WFI were explored and sorted into different themes. In total, 1520 units of meaning were distinguished. The idea in constructing the themes was from the ground upwards (Urquhart 2013). In this process the meaning units were grouped into themes based on the respondents' negative and positive experience of WFI (Guest, MacQueen, and Namey 2012) so that similar ideas were categorized together. As a result, three negative themes in the experience of WFI were detected:

- 'You can't be perfect in every field',

- 'Opportunities refused', and

- 'Tiredness gets you down'.

Additionally, two positive themes were detected:

- 'Taking a learner's perspective', and

- 'More rewarding at home'.

We distinguished one dominant theme under individual coping strategies and one under organizational support for WFI: 'The importance of the wife' and 'Unsupportive organizational cultures', respectively. Our discussion now turns to these themes.

\section{Findings}

\section{You can't be perfect in every field}

WFI as conflict was experienced in both daily routines and life generally. It was accepted as a reality that one cannot escape. The interviewees repeatedly expressed the idea that when answering needs in one domain they deprive the other domain of resources, therefore conflict is programmed. For example, Interviewee D mentions that " a conflict will arise if you don't manage to accomplish everything in time, stay at work too long, it's natural".

Both domains are experienced as demanding, and the efforts made to perform one's roles well in the family and at work are related to sacrifice. Time that the interviewees would have devoted to themselves, their own hobbies and relaxation had to be given to family wellbeing and quality work. Interviewee G says, "just family and work remained, I could not spare any time for sports, any extra activity or leisure time, there wasn 't any time left for that". However, sacrifice was regarded as natural, an inevitable part of handling WFI. For example, Interviewee I said: "some men say that they sacrificed freedom for family, but this is a life stage $<\ldots>$ ". 
These experiences do not contain testimonies about the experience of negative spillover and strain; rather, the lack of resources in each of the roles is viewed as a psycho-socially and morally neutral experience which is taken as an inevitable and obvious outcome of parenthood. The way the interviewees speak about the demands of each role offers a rationalization of the conflict they have experienced, which relieves it.

\section{Opportunities refused}

Negative spillover from family to work can be noticed in career decisions, which become limited. Once managers decide to have a family, they experience pressure for financial security, feel restricted when it comes to taking risks and having more choice in their working life, as exemplified by Interviewee B: “one doesn't take any risky decisions $<\ldots>$ I had some...quite... controversial challenges, meaning, I could be very successful but everything could have burnt suddenly, I could have been left without anything, so of course I refused to make that decision, because <...> less is better with children".

Having a family is also perceived as restricting one's career mobility. Interviewee B mentions that "I could get a job in Brussels. I could get a salary three times higher and social guarantees there, but I was stopped by the thought $<\ldots>$ oh, moving with the children $<\ldots>$ is it worth starting that?". WFI conflict is experienced because of the need to be accessible to the family when needs arise, which leads to refusing opportunities offered for promotion or projects that require traveling abroad. The duties that come with the different family roles prevent one from taking a greater workload and working long hours. Although they would like to work more and/or harder, the interviewees perceive and clearly voice the idea that the family would not allow that and they prioritize family needs over work demands.

Paradoxically, although the interviewees acknowledge the freedom offered by a managerial position to adjust schedules to needs, they also talk about it as a source of family-work conflict. The strain stemmed from one's inability to be in two roles and two different places at the same time. For example, Interviewee J says, "of course one always tries to sacrifice the family less but it happens that you can't call off a meeting". There was the idea that demands created by the family put constraints on the professional role of people in managerial positions and restrict the possibility of working longer hours, for example when one has to finish a project on time, go to a business dinner with partners, or stay in meetings that last longer than planned. 
The experiences of conflict from family to work were related not only to the traditional factor of time constraints and the expectations of efficiency in the work role, as noted by prior research (Greenhaus and Beutell 1985; Runte and Mills 2004), but also to a lack of other (e.g. psychic) resources. Interviewee $\mathrm{K}$, for example, mentions that "tension arises very easily as you are tired, tired from housework $<\ldots>$ if you're tired all the time, there are multiple moments of tension". Tension is experienced as having a negative effect on efficiency at work and work quality, as Interviewee $\mathrm{K}$ goes on to say: "the quality of work goes up and down, but because of fatigue, most likely, I worked less hours than before and I think that work is not as efficient as it used to be". Children's problems seem to be a strong factor in negative emotional spillover, as Interviewee L relates: "your child experiences some hard times, you are anxious about it, this affects your work - your work is affected if you are all churned up inside". These experiences are described as affecting cognitive abilities such as the ability to concentrate.

\section{Tiredness gets you down}

Although family is explicitly prioritized, on a daily basis work takes so much energy that after work interviewees feel too tired to take part in family life, and this is why they experience work-family conflict. The interviewees consider fatigue from work as a source of negative spillover to family life that affects their relationships with members of the family, particularly children. They admit impatience when communicating with their children or a poor quality relationship with them, to quote Interviewee I: "there are days $<\ldots>$ when you just sit down and want to stare at the TV without thinking $<\ldots>$ but here comes your child who wants to play with you and you realize that you haven't played with her, so you switch off the TV and equally bluntly communicate with her: yeh yeh, this is beautiful'. These experiences differ from what LaRossa (1988) called "imitated involvement of fatherhood conduct", that is, a situation where the man tries to look as if he is taking care of the children (to meet the expectations of fatherhood) but is actually watching TV. The interviewee in this study acknowledges the lack of quality in relating, considering tiredness an obstacle to more involved fatherhood. This indicates that he is aware of not meeting the expectations of an involved father, and this is a source of strain to him.

Men recognized that they feel emotionally distant from their children because of the length of time they spend at work: "you leave, she's still asleep and you meet her only in the evening $<\ldots>$ firstly, the relationship became emotionally distant $<\ldots>$ you aren't that important when

you're away most of the time" (Interviewee D). Not giving enough attention and time to the 
family and children was experienced as a source of strain, as acknowledged by Interviewee J: " as far as attention is concerned I feel that I'm a bad father, I should pay more attention to the child". In certain cases, being physically away from the family makes these men uncommitted fathers (Kangas, Lämsä, and Heikkinen 2017) and implies a traditional model of gender roles in dual income families, which puts a bigger share of the housework (and unpaid workload) on women. However, the fact that the interviewees experience strain and self-reproach of a moral nature for being detached from their children indicates movement away from the traditional model.

Nevertheless, the interviewees tended to rationalize the limited time they spent with the family, highlighting the importance of quality rather than quantity. As interviewee E said, "I could improve the quality of the time I spend with the children, increasing the amount of time with them makes no sense to me". This understanding relates to the idea of the "best bits of fatherhood" (Kangas, Lämsä, and Heikkinen 2017), the type that values short-term positive experiences with children (e.g. play) rather than the daily, continual childcare at home that is exemplified here by Interviewee C: "I'm more an object of entertainment for the children, to play football, chess or something".

Another source of work to family conflict for managers is the obligation to be accessible in case of an emergency at work during weekends, holiday and other days off. Male managers experience stress not only from specific role functions but from more general ones, such as responsibility for the future of the business and the employees. As many of the interviewees reported, one cannot close the door behind one when one leaves work and forget all about it. Stress at work affects family life, making it less harmonious.

\section{Taking a learner's perspective}

One theme which stressed enrichment from family life to working life was taking a learner's perspective. A dominant idea here was the transfer of skills. Interviewees mention the improvement of social skills at home such as seeking compromise, showing attention and/or complimenting another person, reaching mutual understanding, and the like, as important to their work. For instance, the learning of social skills was mentioned as an aspect of family life that enriches work. In particular, relating to children who have not yet absorbed the cultural and social norms and are not always able to conceal their spontaneous reactions was seen as a resource for developing emotional intelligence and enriching the work domain. For example, 
Interviewee E mentions, "children teach you in essence $<\ldots>$ they improve the quality of communication because you observe children's reactions, and the reactions of adults are the same, just they conceal them".

The men said that self-realization and personal development are important aspects of the experience of fatherhood that can be useful at work. Importantly, the family domain is considered just as important as professional activity for personal development and harmony in life. Some interviewees see direct parallels between family and company life, e.g., as Interviewee $\mathrm{H}$ relates, "family gatherings are no different from discussions in the company, all the management bodies like board meetings or committee meetings that are developed in the company have analogies in the family". Although this idea supports the image of WFI as bidirectional enrichment, it implies familial characteristics in the organization as well. Enrichment from family to work is experienced as positive and is not seen as conflicting but rather as balanced. These experiences rest on the basis of the values and identity development of a successful person, which not only includes status and earnings in professional life, like in the traditional image of masculinity, but also draws on family life and the strengthening perceptions of involved fatherhood.

In some interviews there was a suggestion of a parallel between an organization and a family: the manager as patriarch of the family who treats employees as children. This underlines the importance of creating qualitative relationships in both cases and navigating between the roles of friend and teacher. Interviewee E, for example, explains, "there is an understanding that all employees are like children, the same rules apply to them $\langle\ldots>$ one doesn't have to teach them". This image of a father-manager may even be accepted by employees, as Interviewee J says: "I drive my colleagues to lunch, there are four seats in the car and there are five people who want to go in my car, so once they joked $<\ldots>$ which of them I would leave behind $<\ldots>$ but I refused to play these games of which one I love more". Seeing a parallel between children's manipulative behavior and that of employees implies that the family domain could be enriching the managerial role from a social perspective. One's experience bringing up the family allows one to understand someone else with the same or similar issues.

However, the overarching idea in this theme draws strongly on a traditional understanding of masculinity, i.e., the breadwinner's perspective. Responsibility for the family and especially an increase in family size were seen as the stimulus for a career breakthrough, and stronger 
motivation to give the family financial stability. Interviewee $\mathrm{H}$ offers an example: "this [family] has become an important goal in my life, so I began to put some effort into realizing myself, firstly, to create a financial basis, because that is important". New additions to the family are also a motive to be more efficient at work: when a person wants to spend more time with the family, they try to be more efficient at work. Here the idea of efficiency and struggling over limited time resources, which is a dominant topic in work-family conflict (Runte and Mills 2004), is turned to the experience of enrichment, which may be interpreted as indicating a shift towards a more active and committed fatherhood.

\section{More rewarding at home}

Improved socialization skills was mentioned also in relation to work to family enrichment. In particular, relating to colleagues was seen as a positive influence on relations in the family, as e.g. Interviewee C relates: "you meet well-educated people in your career, $<\ldots>$ you get ideas [from them] what you could do in your family". Besides, having a professional career and being away from the family for some time during the day are perceived as positive influences on family life, enabling meaningful communication in the family. Interviewee E, for example, says: "If I stayed at home it would be much worse, and now we don't have time to fight, talk about trivialities, our time in the family is spent only in talking about meaningful things". In such cases one can question what is meant by "trivialities": it may mean avoiding routine housework issues, and "meaningful" may denote staying in the realm of the metaphysical and avoiding the pragmatic, so it does not necessarily guarantee WFI to the interviewee's spouse even when it does so to the male interviewee.

In these experiences, holding a position in management is a factor that facilitates positive WFI. The interviewees spoke about the possibility of managing their schedule more flexibly and, if necessary, of giving the family more attention. For example, Interviewee J reports: "I'm happy to have a management position and when necessary I can make arrangements; if I had a lower position I think it would be more complicated, in some sense even worse for the child because she wouldn't get attention when it's needed". The interviewees have more flexibility to plan not only their time but also their workload. This is in line with the findings of Nomaguchi, Milkie and Bianchi's (2005) research, that more qualified occupations and higher positions in organizations are positive factors in achieving work-family balance.

\section{The importance of the wife}


When talking about their experiences of applying coping strategies in WFI conflict, the interviewees mostly spoke about help from another person, as does Interviewee J: "sometimes it happens that I can't cancel a meeting so then I start searching for someone I can leave the child with". The attempt to cope with the difficulties of integrating role responsibilities and functions is not systematic, but rather haphazard. This is a similar to a coping strategy used by women when they experience work-family conflict (Graham and Dixon 2017; Reingardienè 2004).

From a long-term and system-based perspective, coping relies strongly on the wife's presence and on her taking on most of the responsibilities at home. The wife is seen as important to overcoming the barriers to the husband's progress in a career that are erected by having a family. For example, looking back, Interviewee A says, "I didn't have time for home at all, meaning, my wife managed the home domain, so the question didn't arise, it was quite natural that I was occupied with a completely different activity and my wife's merit is that I could do that". Taking responsibility for the lion's share of the housework and for daily childcare is (still) seen as primarily the wife's role, although the interviewees tended to acknowledge that responsibility for taking care of children rests with both partners, as e.g. Interviewee I notes: "my wife cooks the dinner, everything is just fine with her, but I sometimes try to stop her, telling her that she doesn't have to iron my shirts or something 〈...> I try to make that clear to her, but she's understanding and doesn't pay attention to what I say“. So at the surface level men demonstrate an awareness of equal rights but when it comes to actually distributing the housework equally it is considered more comfortable to go on with the status quo. Coping in this sense, then, involves staying in the comfort zone and not enacting social expectations.

Some interviewees mentally and physically transferred housework tasks to the wife, attributing their lack of participation in the family to their being untalented on the grounds that they lacked talent. Interviewee B, for example, mentions, “I can't do something, so I don't do it, don 't wash or iron something", but claims that he is more capable in other, "more manly" fields such as repairing the car, or looking after the outside of the house and the garden.

\section{Unsupportive organizational cultures}

Men do not often rely on the benefits provided by legislation in relation to paternity to reduce the strain arising from the demands they meet at work. Interviewee I, who works in a maledominated company, states that "such things as exceptions, paternal leave of one day a month 
and so on don't exist [in the company]" and offers an explanation: "we're a simple company that grew from local agents $<\ldots>$ and the attitude is Lithuanian", which means operating under a liberal market economy with little concern for employees' needs.

Moreover, co-employees' attitudes are not favorable to family-friendly practices, even if the needs are recognized to exist. As Interviewee G says, "in our organization, I started taking days off for paternity leave and there were unfriendly looks, although they all have children". Such an organizational context can be considered to contribute to conflict between work and family, and it suggests the traditional way of thinking, that obligations at work are more important than family obligations. If a male manager takes longer than usual paternity leave, he feels obliged to return to work before the legally granted period ends as there is "so much work" to do - and this is regarded as self-evident. Using the opportunities provided by law becomes emotionally much simpler when informal agreements are made with higher managers, as Interviewee G mentions: "my supervisor has children of a similar age, so you just have to ask and everything is clear, you just say that you'll give results". It is important to note here that most of these experiences were shared by interviewees in mid-management positions.

\section{Discussion and conclusions}

In writing this article we aimed to increase understanding of men's masculinity in the postSoviet context by contributing specifically to the shortage of research on men with children in the intersection of work and family. We particularly sought to make men managers more visible as fathers and husbands, studying their experiences of WFI, what strategies they used when they experienced conflict, and the role of the organization in these experiences. This is one of the first studies focusing on male managers' experience of WFI in Lithuania and the Baltic countries.

The findings make clear that men managers experience WFI more as conflict than as enrichment. In this respect our findings contradict those from other socio-cultural contexts like Finland (Kangas, Lämsä, and Heikkinen 2017), where men managers do not tend to experience WFI as conflict - or at least they do not easily reveal such experience in a research setting. The sources of tension between work and family among Lithuanian men managers are established in the mainstream management literature and include a lack of time, changes in work schedules, and the overlapping duties of different roles at the same time (Greenhaus and Beutell 1985; Runte and Mills 2004). Work is experienced as a source of negative spillover to the family, 
reducing the quality of the manager's relationship with his family and distancing him from his children.

Our findings are in contrast to prior studies which showed that work tends to be a source of negative spillover in the family for men (Fitzpatrick et al. 2012; Gatrell et al. 2013; Nomaguchi, Milkie, and Bianchi 2005). Experiences of family-work conflict were rich in content in this study. The family was seen as mostly restricting career choices, prompting less risky and less work-intense decisions in the professional sphere. The descriptions of these experiences imply that a man feels obliged not only to take the role of breadwinner who guarantees financial security and stability to the family but also to some extent the role of care-giver on a daily basis. This signals some kind of shift in the way men experience masculinity now, specifically, moving from a traditional fatherhood to a more involved one. This can signal some ongoing change in men's gender roles in Lithuanian society in general.

The experiences of the men managers studied here construct specifically an image that has been called the "best bits of fatherhood" by Kangas, Lämsä, and Heikkinen (2017) or "new fatherhood" by Kaufman (2013). Such an idea seemed to be a dominant identity of fatherhood in this study. These categories stress balancing the breadwinner's and the care-giver's roles, spending more time with the family on weekends rather than every day. In particular, our research findings fit with the characteristics of the category of "new fatherhood", which recognizes the work-family conflict and men's inability to achieve satisfaction in both roles. This differs from the extremes of both the "uncommitted" and "traditional" or the "involved fatherhood" and "superdad" categories. Men in the traditional masculine role see themselves as breadwinners and demand that their wives take responsibility for child-rearing and housework (Kangas, Lämsä, and Heikkinen 2017; Kaufman 2013). Men who see themselves as involved fathers usually see their role as care-giver as more important than their breadwinner's role, and integrate both domains successfully by adjusting their work tasks to meet family needs. The emerging discourse of enrichment among male managers in our study, which they equate with personal growth and, in particular, the advancement of social skills and empathy, is also indicative of men acquiring the attitudes and behavior needed to fulfill the care-giver's role with higher self-efficacy, which has the potential to change the prevailing social discourse that equates masculinity with being the breadwinner. 
Yet, despite the changes in the men's experiences of masculine identities in this study, individual coping strategies in work-family conflict among manager-fathers ranged from rationalizing conflict as natural, temporary and thus endurable through reliance on the help of capable others in the case of emergency child-care, to relying completely on the wife's presence and on her taking responsibility for the housework and childrearing. Although men may perceive that there is inequality in the distribution of housework, they may still choose to refrain from enacting a more equal relationship. This can be explicitly ascribed to the traditional understanding of the family model as patriarchal, with clearly distinguished gender roles and gender-typical tasks. This also maintains the distribution of tasks of each role that was established in Soviet times: the woman is not seen as a housewife and she is expected to be economically active, but housework is not shared equally (cf. Reiter, 2010). However, this is not necessarily a characteristic only of the post-Soviet context, as Reddick et al. (2012) found similar tendencies in the attitudes and behavior of academic fathers in the UK: despite their declared personal support for equal rights in the family and their determination to share household duties and child rearing, they still tended to retreat to traditional gender roles when coping with work-family conflict. Such experiences support the image of "uncommitted fatherhood" or, in more modern families, "best bits of fatherhood".

In this study, organizations were experienced as family unfriendly and, from the institutional or systemic perspective, as contributing to conflict. This can be related to the post-Soviet sociocultural context and the young liberal market economy model, in which everyone tries to be successful on the strength of their own efforts rather than acting collectively. Pučètaitè, Lämsä, and Novelskaitė's (2010) research on ethical human resource management practices in a postSoviet context yielded similar findings: Lithuanian organizations were lagging behind foreign companies in the voluntary implementation of organizational practices that promote employees' well-being and build organizational trust. A mitigating factor in the tensions experienced is supervisors' and managers' own experience of integrating work-family responsibilities. In the case of middle management, the individual manager's relationship with his/her supervisor has been found to ease the strain. This is in line with Plaisier et al. (2015) in their study on the interface between work and informal caregiving, an increasingly popular topic of academic research due to the aging society in many countries. However, this contrasts with the findings from other studies (Reddick et al. 2012), in which men demonstrated empathy with colleagues' concerns over family issues. This could be explained by the post-Soviet mentality: in Soviet times, there was solidarity behind social welfare only in theory: the reality 
often privileged the nomenclature rather than the individual. Therefore people's ability to cooperate and act collectively in this context is still inadequate (cf. Pučètaitè, Jurènienè, and Novelskaite 2014). However, our research does not yield any evidence that top managers will be drivers of systemic practices to build more rewarding workplaces in terms of WFI.

Our findings have strong managerial implications, particularly as regards bringing about changes in human resource management practices in Lithuanian organizations. As proposed by Mastracci and Arreola (2016), human resource management practices are among the most influential ones when deconstructing stereotypes and expectations in gendered organizational practices. Our findings indicate that strengthening favorable attitudes to family-friendly practices among employees may lead to the implementation of political programs for equality and the enforcement of legal measures which, as reported by Dulk et al. (2010) in a study that covered 19 central and East European countries, have so far failed to gain employers' support. This might also lead to employers' involvement in extra-statutory child-care and leave arrangements.

To conclude, the findings of this study suggest that some change is happening in male managers' individual experiences and that there is a move towards more involved fatherhood in the post-Soviet context studied here. This will challenge organizations and institutions in the future to make it more possible for men to integrate work and family life. However, because the traditional masculine way of acting seemed to emerge when there was a conflict between work and family, the findings allow us also to conclude that despite the fact that the men's experience of masculinity is in flux, the change from traditional masculinity to a caring masculinity such as involved fatherhood may not in fact come about very quickly or profoundly in this context.

Our research is not without limitations. Firstly, although our questionnaire was based on a narrative approach, some of the questions directly asking about, e.g. the role of the wife but not a wider network of support such as grandparents, siblings, close friends, neighbours etc. may have directed the interviewees' reflection to the spouse merely. As prior research indicates the importance of wider networks for WFI (Graham and Dixon 2017; Reingardienè 2004) further research of fathers managers' experiences of WFI should enquire more in-depth in the role of wider networks when coping with WFI as conflict. Moreover, design of similar studies in the future could benefit from post-interviews which we did not carry out. Post-interview 
reflections may yield richer narratives of coping strategies. Secondly, our 12 interviewees were not homogeneous in their position (mid-managers and top managers). Larger samples of each group could yield richer narratives, which would make it possible to reach more analytically generalizable and more plausibly interpreted conclusions. Further research could explore the experiences of these groups more deeply. Among top managers, it would be worth examining further both the construction of paradoxes like the one that emerged when describing time constraints, and the flexibility provided by a managerial role. Thirdly, another aspect for further research relates to expanding interviewees' social background. Notably, all our interviewees were married to mothers of their children and lived together with them. Including men who are divorced, separated or living together with a partner to whom they are not married into the sample may generate richer representations of masculinity in society. Moreover, as noted by Fitzpatrick et al. (2012), single parents rarely achieve top positions in organizations which enable and empower them to achieve WFI and experience enrichment from their roles in different domains. We therefore suggest that further research could enquire into the experiences of WFI among single fathers in management position to increase the knowledge about enabling factors.

\section{References}

1. Acker, J. 1990. "Hierarchies, Jobs, Bodies: A Theory of Gendered Organizations". Gender and Society 4 (2): 139-158.

2. Allen, T. D., D. E. L. Herst, C. S. Bruck, and M. Sutton. 2000. "Consequences Associated with Work-to-Family Conflict: A Review and Agenda for Future Research”. Journal of Occupational Health Psychology 5 (2): 278-308.

3. Aspers, P. 2009. "Empirical Phenomenology: A Qualitative Research Approach". Indo-Pacific Journal of Phenomenology 9 (2): 1-12.

4. Bailyn, L. 2011. "Redesigning Work for Gender Equity and Work-Personal Life Integration". Community, Work \& Family 14 (1): 97-112.

5. Bandura, A. (1977). Social Learning Theory. Englewood Cliffs, NJ: Prentice-Hall.

6. Berger, P. L., and T. Luckmann. 1966. The Social Construction of Reality. New York: Penguin Putnam Inc.

7. Bianchi, S. M., and M. A. Milkie. 2010. "Work and Family Research in the First Decade of the 21st Century". Journal of Marriage and Family 72 (3): 705-725.

8. Bruner, J. S. 1991. "The Narrative Construction of Reality". Critical Inquiry 18 (1): 121. 
9. Bučaitè-Vilkè, J., and A. Tereškinas. 2016. "Lithuanian Men's Struggles with Precarious Life: Unemployment, Working Identities, and Strategies of Survival”. Journal of Baltic Studies 47 (2): 197-218.

10. Carlson, D. S., J. G. Grzywacz, and S. Zivnuska. 2009. "Is Work-Family Balance More than Conflict and Enrichment?" Human Relations 62 (10): 1459-1486.

11. Castro-García, C., and M. Pazos-Moran. 2016. "Parental Leave Policy and Gender Equality in Europe". Feminist Economics 22 (3): 51-73.

12. Connell, R. W. (1995). Masculinities. Cambridge, UK: Polity Press.

13. Crespi, I., and E. Ruspini. 2015. "Transition to Fatherhood: New Perspectives in the Global Context of Changing Men Identities”. International Review of Sociology 25 (3): 353-358.

14. Doldor, E., D. Anderson, and S. Vinnicombe. 2013. "Refining the Concept of Political Will: A Gender Perspective". British Journal of Management 24 (3): 414-427.

15. Drews, L. V., F. W. Cybulski, I. V. Gíslason, G. H. Atlason, J. Reingardienè, A. Tereškinas, A. Zdanevičius, and C. Callus. 2005. "Father on Parental Leave: A Joint Report Based on Qualitative Research with Fathers on Leave, Employers and Decision Makers in Lithuania, Iceland, Denmark and Malta”. Vilnius: Eugrimas, Center for Equality Advancement. http://gap.lt/wp-content/uploads/2014/02/Fathers-on-ParentalLeave.pdf.

16. Dulk, den L., P. Peters, E. Poutsma, P. E. M. Ligthart. 2010. "The Extended Business Case for Childcare and Leave Arrangements in Western and Eastern Europe". Baltic Journal of Management 5 (2): 156-184.

17. Eagly, A. H., and W. Wood. 2012. "Social Role Theory". In Handbook of Theories of Social Psychology edited by Van Lange, P. A. M., A. W. Kruglanski, and E. T. Higgins, 458-476. Thousand Oaks, CA: Sage Publications.

18. Fitzpatrick, T., B. Janzen, S. Abonyi, and I. Kelly. 2012. "Factors Associated with Perceived Time Pressure among Employed Mothers and Fathers”. Psychology 3 (2): 165-174.

19. Gatrell, C. J., S. B. Burnett, C. L. Cooper, and P. Sparrow. 2013. "Work-Life Balance and Parenthood: A Comparative Review of Definitions, Equity and Enrichment". International Journal of Management Reviews 15: 300-316.

20. Goode, M. J. 1960. “The Theory of Role Strain”. American Sociology Review 25 (4): 489-496. 
21. Graham, J. A., and M. A. Dixon. 2014. "Coaching Fathers in Conflict: a Review of the Tensions Surrounding the Work-Family Interface". Journal of Sport Management 28: 447-456.

22. Graham, J. A., and M. A. Dixon. 2017. "Balance among Coach fathers: A Qualitative Examination of Enrichment, Conflict, and Role Management Strategies". Journal of Sport Management 31: 288-305.

23. Greenhaus, J. H., and N. J. Beutell. 1985. "Sources of Conflict between Work and Family Roles". Academy of Management Review 10: 76-88.

24. Greenhouse, J. H., and G. N. Powell. 2006. "When Work and Family Are Allies: A Theory of Work-Family Enrichment”. Academy of Management Review 31: 72-92.

25. Grzywacz, J. G., and N. F. Marks. 2000. "Reconceptualizing the Work-Family Interface: An Ecological Perspective on the Correlates of Positive and Negative Spillover Between Work and Family". Occupational Health Psychology 5 (1): 111126.

26. Guest, G., K. M. MacQueen, and E. E. Namey. 2012. "Introduction to Applied Thematic Analysis". In Applied Thematic Analysis edited by Guest, G., K. M. MacQueen, and E. E. Namey, 3-20. Thousand Oaks, CA: Sage.

27. Haas, L., and C. P. Hwang. 2013. "Trade Union Support for Fathers' Use of WorkFamily Benefits - Lessons from Sweden”. Community, Work and Family 16 (1): 4667.

28. Heikkinen, S. 2015. "(In)significant Others: The Role of the Spouse in Women and Men Managers' Careers in Finland”. PhD diss., University of Jyväskylä.

29. Heikkinen, S., and A.-M. Lämsä. 2017. "Narratives of Spousal Support for the Careers of Men in Managerial Posts". Gender, Work and Organization 24 (2): 171-193.

30. Hobson, B. 2011. "The Agency Gap in Work-Life Balance: Applying Sen's Capabilities Framework within European Contexts”. Social Politics 18 (2): 147-167.

31. Hobson, B., and S. Fahlen. 2009. "Competing Scenarios for European Fathers: Applying Sen's Capabilities and Agency Framework to Work-Family Balance”. ANNALS, AAPSS 624: 214-233.

32. Juraitė, K., and A. Zdanevičius. 2004. "Lyčių lygybès vertinimai ir Lietuvos viešoji nuomone” [Evaluations of Gender Equality and Lithuanian Public Opinion]. Sociologija. Mintis ir veiksmas 3: 95-109. 
33. Kangas, E., A.-M. Lämsä, and S. Heikkinen. 2017. "Father Managers (Un)doing Traditional Masculinity". In Fatherhood in Contemporary Discourse - Focus on Fathers edited by A. Pilinska, 17-30. Oxford: Cambridge Scholars Publishing.

34. Kaufman, G. 2013. Superdads: How Fathers Balance Work and Family in the $21^{\text {st }}$ Century. New York: New York University Press.

35. Kaufman, G. 2018. "Barriers to Equality: Why British Fathers Do Not Use Parental Leave", Community, Work \& Family, 21 (3): 310-325.

36. Lammi-Taskula, J. 2006. "Nordic Men on Parental Leave". In Politicising Parenthood in Scandinavia edited by Ellingsaeter, A., and A. Leira, 79-100. Bristol: Policy Press.

37. LaRossa, R. 1988. "Renewing our Faith in Qualitative Family Research". Journal of Contemporary Ethnography 17 (3): 243-260.

38. Lämsä, A-M., T. Auvinen, S. Heikkinen, and T. Sintonen. 2018. "Narrativity and its Application in Business Ethics Research". Baltic Journal of Management 13(2): 279296.

39. Lewis, S. 1997. “'Family friendly' employment policies: A route to changing organizational culture or playing about at the margins?" Gender, Work and Organization 4 (1): 13-23.

40. Mäkelä, L., A.-M. Lämsä, S. Heikkinen, and J. Tanskanen. 2017. "Work-to-PersonalLife Conflict among Dual and Single-Career Expatriates-Is It Different for Men and Women?” Journal of Global Mobility 5 (3): 304-316.

41. Mastracci, S., and V. I. Arreola. 2016. "Gendered Organizations: How Human Resource Management Practices Produce and Reproduce Administrative Man”. Administrative Theory \& Praxis 38: 137-149.

42. Mihelič, K. K. 2014. "Work-Family Interface, Job Satisfaction and Turnover Intention: A CEE Transition Country Perspective”. Baltic Journal of Management 9 (4): 446-466.

43. Nomaguchi, K. M., M. A. Milkie, and S. M. Bianchi. 2005. "Time Strain and Psychological Well-Being: Do Dual-Earner Mothers and Fathers Differ?" Journal of Family Issues 26: 756-792.

44. Oates-Indruchova, L. 2006. "The Void of Acceptable Masculinity During the Czech State Socialism: The Case of Radek John's Memento". Men and Masculinities 8 (4): 428-450.

45. Parasuraman, S., and J. H. Greenhouse. 2002. "Towards Reducing Some Critical Gaps in Work-Family Research”. Human Resource Management Review 12: 299-312. 
46. Parsons, T., and R. F. Bales. 1955. Family, Socialization and Interaction Process. Glencoe, IL: Free Press.

47. Plaisier, I., M. I. Broese van Groenou, and S. Keuzenkamp. 2015. "Combining Work and Informal Care: The Importance of Caring Organisations". Human Resource Management Journal 25 (2): 267-280.

48. Pučètaitè, R., V. Jurènienè, A. Novelskaitè. 2014. "Lithuania: CSR on a Wishlist". In Trade Unions and Corporate Social Responsibility in Europe edited by Preuss, L., Gold, M., and C. Rees, 100-117. London: Routledge.

49. Pučètaitè, R., A.-M. Lämsä, and A. Novelskaitè. 2010. "Organizations Which Have the Strongest Potential for High-Level Organizational Trust in a Low-Trust Societal Context". Transformations in Business and Economics 9 (2): 318-334.

50. Purvaneckas, A. and G. Purvaneckienè. 2001. Moteris Lietuvos visuomeneje [Woman in Lithuanian Society]. Vilnius: Danielius.

51. Reddick, R. J., A. B. Rochlen, J. R. Grasso, E. D. Reilly, and D. D. Spikes. 2012. “Academic Fathers Pursuing Tenure: A Qualitative Study of Work-Family Conflict, Coping Strategies and Departmental Culture". Psychology of Men and Masculinity 13: $1-15$.

52. Reingardienè, J. 2004. "Moterų karjeros ir šeimos dilemos" [Women's Dilemmas between Career and Family]. Sociologija. Mintis ir veiksmas 1: 59-72.

53. Reiter, H. 2010. "In My Opinion, Work Would Be in First Place and Family in Second': Young Women's Imagined Gender-Work Relations in Post-Soviet Lithuania”. Journal of Baltic Studies 41 (4): 531-551.

54. Riska, E., and A. Novelskaitè. 2008. "Professionals in Transition: Physicians' Careers, Migration and Gender in a Post-Soviet Era". In Rethinking Professional Governance: International Directions in Health Care edited by Kuhlmann, E., and M. Saks, 217230. Bristol: Policy Press.

55. Runte, M. and A. J Mills. 2004. "Paying the Toll: A Feminist Post-Structural Critique of the Discourse Bridging Work and Family”. Culture and Organization 10 (3): 237249.

56. Sieber, S.D. 1974. "Toward a Theory of Role Accumulation". American Sociological Review 39 (4): 567-578.

57. SODRA. 2018. "Portal of Statistics". http://atvira.sodra.lt/lt-eur/ Accessed on March $30,2018$. 
58. Šumskaitè, L. 2014. "Norminis vyriškumas tėvystès praktikose" [Normative Masculinities in Fathering Practices]. Socialine teorija, empirija ir praktika 8: 33-50.

59. Tereškinas, A. 2004. "Tarp norminio ir subordinuoto vyriškumo formų: vyrai, jų seksualumas ir maskulinizmo politika šiuolaikinèje Lietuvoje" [Between Hegemonic and Subordinated Masculinities: Men, Their Sexuality and Politics of Masculinity in Contemporary Lithuania]. Sociologija. Mintis ir veiksmas 3: 28-38.

60. Tereškinas, A. 2006. "Vyriškumas ir tėvystė: Lietuvos vyrų tèvystès atostogose atvejis". Lyčiu studijos ir tyrimai / Gender Studies and Research 2: 90-96.

61. Tereškinas, A. 2009. "Social Suffering, Post-Soviet Masculinities and Working Class Men”. Social Sciences/Socialiniai mokslai 2(64): 79-88.

62. Tereškinas, A. 2014. "Masculinity Scripts, Good Life and Familial Intentions: The Case of Young Lithuanian Men”. Social Sciences 4(86): 44-53.

63. Urquhart, C. 2013. Grounded Theory for Qualitative Research: Practical Guide. London: Sage.

64. Valackienè, A. 2003. "Profesinę karjerą sąlygojantys veiksniai: subjektyvus vertinimas" [Factors Determining Professional Career: Subjective Evaluation]. Profesinis rengimas: tyrimai ir realijos 7: 110-127. 